2015

\title{
Litigation Holds: Past, Present, and Future Directions
}

\author{
Milton Luoma \\ Metropolitan State University \\ Vicki M. Luoma \\ Minnesota State University
}

Follow this and additional works at: https://commons.erau.edu/jdfs|

Part of the Computer Engineering Commons, Computer Law Commons, Electrical and Computer Engineering Commons, Forensic Science and Technology Commons, and the Information Security Commons

\section{Recommended Citation}

Luoma, Milton and Luoma, Vicki M. (2015) "Litigation Holds: Past, Present, and Future Directions," Journal of Digital Forensics, Security and Law. Vol. 10 : No. 1 , Article 5.

DOI: https://doi.org/10.15394/jdfsl.2015.1198

Available at: https://commons.erau.edu/jdfsl/vol10/iss1/5

This Article is brought to you for free and open access by

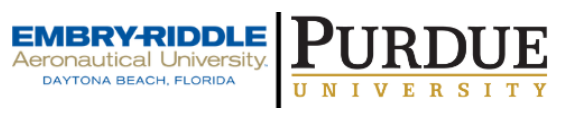
the Journals at Scholarly Commons. It has been accepted for inclusion in Journal of Digital Forensics, Security and Law by an authorized administrator of Scholarly Commons. For more information, please contact commons@erau.edu.

(c)ADFSL

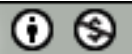




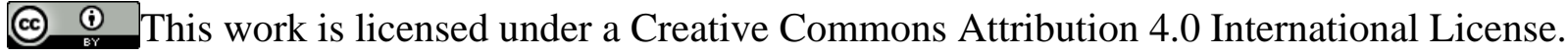

\title{
LITIGATION HOLDS: PAST, PRESENT AND FUTURE DIRECTIONS
}

\author{
Milton Luoma \\ Metropolitan State University \\ St. Paul, Minnesota \\ Vicki M. Luoma \\ Minnesota State University \\ Mankato, Minnesota
}

\begin{abstract}
Electronically Stored Information (ESI) first became a serious litigation issue in the late 1990s, and the first attempts to determine best practices did not occur until the early 2000s. As best practices developed, the litigation hold to prevent routine destruction of documents and to preserve documents relevant to litigation came into existence. The duty to preserve ESI is triggered when litigation is reasonably anticipated. All information that relates to potential litigation must be preserved from the time it becomes reasonably apparent that litigation is possible until the expiration of the statute of limitations. If steps are not taken to properly collect, preserve, and produce such information for the discovery phase of litigation, the fear is that justice may be perverted. In addition electronically stored information destroyed negligently or intentionally may well be lost forever and result in the litigant being sanctioned.

For the first seven years of the new e-discovery rules, litigants who failed to preserve data received severe sanctions for spoliation of evidence. Recent cases and proposed new rules have reversed the decade-long trend of stringent standards requiring litigation holds leaving the state of the law in flux in spite of the fact that accepted best practices do recommend high standards for litigation holds. This paper reviews this conflict in the law and offers recommendations for future directions.
\end{abstract}

Keywords: Litigation hold, Electronic Discovery, ESI, Preservation 
(c) () This work is licensed under a Creative Commons Attribution 4.0 International License

Litigation holds have been with us for about a decade since the series of Zubulake motions beginning in 2003. A litigation hold is an act of an individual or organization to prevent the routine destruction of documents when they know or should know that a lawsuit is likely (Montanta Lawyer). The procedure includes the issuance of a formal notice to the custodian of records either verbally or in writing to cease routine deletion of records of all types-electronic or non-electronic-that may be or may become relevant in the event of litigation (Josh Rosenberg Potential New Roles for Law Firms in Litigation 2012). The Sedona Conference has recommended this policy as a best practice since 2004 when courts first outlined best practices for litigation or potential litigation (Sedona).

\section{PAST PRACTICES}

Electronically Stored Information (ESI) has been the subject of cases, court orders, papers and conferences. A majority of the cases involving ESI concern the retention of data. One major question was whether a party should be sanctioned if the failure to preserve data was simple negligence. Courts often looked to see whether the litigant was timely in issuing a litigation hold and maintaining the litigation hold throughout the litigation. The requirement of a litigation hold had become the standard practice after Zubulake even though the revisions to the Federal Rules of Civil Procedure adopted in 2006 did not make litigation holds a mandatory requirement. The only mention of the litigation hold in the new rules was in the Committee notes and stated, "if a party is under a duty to preserve information because of pending or reasonably anticipated litigation, intervention in the routine operation of an information system is one aspect of what is often called a 'litigation hold." (Committee note FED R. CIV. P. 37(f) 2006). The prestigious, Sedona Working groups, a nonprofit research and education institute dedicated to the advance study of law and policy including e-discovery, issued Best Practices in ESI and made Litigation Holds an integral segment of compliance procedure (Sedona 2010 and 2007).

Even though the rules did not require litigation holds, several courts have issued sanctions for failure to institute and maintain a litigation hold. In Silvestri v. General Motors, the court found that the requirement to institute a litigation hold "arise[s] not only during litigation but also extends to that period before the litigation when a party reasonably should know that the evidence may be relevant to anticipated litigation." (Silvestri v General Motors, 2001).

The trend for the first seven years was to increase the severity of sanctions. Almost 10 years after Judge Shira Scheindlin's Zubulake decisions established the requirement of litigation holds when events occur that a reasonable person might expect to lead to litigation, the question remains whether the failure to issue a litigation hold to prevent the destruction of relevant documents constitutes gross negligence thereby warranting sanctions against a party or a party's lawyers? In the Zubulake decision the court found "[o]nce a party reasonably anticipates litigation, it must suspend its routine document retention/destruction policy and put in place a 'litigation hold.' (Zubulake)

Under the fear of sanctions, businesses established teams and procedures to be in compliance with retention and deletion policies as well as litigation holds. Sanctions have included everything from monetary damages to summary judgment. Judge Scheindlin leaves no doubt in her recent decisions by emphatically asserting that such 
(c) () This work is licensed under a Creative Commons Attribution 4.0 International License

behavior does constitute gross negligence requiring the imposition of judicial sanctions. The Sedona Conference's best practices guidelines also agree that a litigation hold is essential to fair discovery as required under the Federal Rules of Civil Procedure. Yet, in spite of these assertions, according to one study $55 \%$ of companies do not issue litigation holds or do not track them to be certain they are followed if they are issued (Governance, 2012).

There has been an attempt in the past decade to establish reasonable best practices to offer guidance to litigators that would facilitate smooth and effective discovery processes for all litigants. Litigation holds are critically important in the case of electronically stored information (ESI) because such a high percentage of business information is held only in electronic form. If those records are deleted and purged from a party's system, there may well be no other evidence available relevant to litigation that may result.

Both ethical and legal consequences to attorneys who fail to inform or to direct their clients on legal holds can result. (Pension Comm. of the Univ. of Montreal Pension Plan v. Bank of Am. Sec., LLC,, 2009) The courts will look at the reasonableness of the effort and good faith efforts of both the client and the attorney (Crystal, 2010).

One of the earliest cases in which the court attempted to set rules concerning ESI was the series of Zubulake motions decided between the years of 2003 and 2005 in the United States District Court for the Southern District of New York with the Honorable Judge Shira Scheindlin presiding. (Zubulake v. UBS Warburg, 2004) This case began as an employment law dispute and retaliation case but is best known for Judge Scheindlin's rulings on ESI and the parties' responsibilities to store and retrieve ESI information. (Zubulake v. UBS Warburg). One of the key elements in the Zubulake case was the requirement that a litigation hold must be issued to preserve potential evidence relevant in the case. As noted by Judge Scheindlin:

"The obligation to preserve evidence arises when the party has notice that the evidence is relevant to litigation or when a party should have known that the evidence may be relevant to future litigation." (Zubulake v. UBS Warburg, 2004)

Further, Judge Scheindlin described the litigants' duty as follows:

"While a litigant is under no duty to keep or retain every document in its possession . . . it is under a duty to preserve what it knows, or reasonably should know, is relevant in the action, is reasonably calculated to lead to the discovery of admissible evidence, is reasonably likely to be requested during discovery and/or is the subject of a pending discovery request." (Zubulake v. UBS Warburg, 2004)

When the Federal Rules of Civil Procedure rules were amended in 2006, the Rules attempted to codify the evolving obligation for potential parties to litigation to collect, preserve, and produce electronically stored information that may become relevant in litigation. Except for a mention in the Rule 37(f) note, which referred to the use of a "litigation hold" as a method of implementation, the Federal Rules do not detail specific requirements about how or when to collect and preserve electronically stored information, and do not include a specific requirement of implementing a litigation hold (Fed.R. C.P 37 (F), 2006). 
(c) () This work is licensed under a Creative Commons Attribution 4.0 International License

However, best practices since the 2006 amendments have included a requirement of a litigation hold. (Sedona Working Group on Electronic Document Retention and Production, 2007) Best practices include once a party receives notice of a lawsuit, a litigation hold could be implemented by means of verbal notice, a written notice, or by email. The notice should direct key individuals to identify and locate records and to suspend routine destruction of these documents. Any preservation notice must clearly specify the desired tasks and notify the correct individuals. The notice should inform the custodians of the information how to identify the correct data and how to preserve it. The litigation hold should be clear as to consequences of not following the hold. The recipients of the litigation hold should be required not only to acknowledge of the notice, but that it is fully understood, including the consequences of not following through with the requirements of the litigation hold. Further, the person in charge should follow up to make sure that everyone is following the instructions (Sedona Working Group on Electronic Document Retention and Production, 2007).

The prestigious Sedona Conferences and principles often cited by courts and followed by businesses, established a set a principles in 2007 (Sedona Working Group on Electronic Document Retention and Production, 2007). The Sedona Conference is a working and thinking group consisting of over seven groups that have produced over 31 publications on various subjects on ESI. These working papers make suggestions on how companies can insure effective data management in a method that will comply with litigation requirements. In addition, the Sedona Working Group has produced the 14 Sedona Principles on best practices summarized as follows:
1. Electronic data and documents are potentially discoverable under Fed. R. Civ. P. 34 or its state law equivalents. Organizations must properly preserve electronic data and documents that can reasonably be anticipated to be relevant to litigation.

2. When balancing the cost, burden and need for electronic data and documents, courts and parties should apply the balancing standard embodied in Fed. R. Civ. P. 26(b)(2) and its state-law equivalents, which require considering the technological feasibility and realistic costs of preserving, retrieving, producing and reviewing electronic data, as well as the nature of the litigation and the amount in controversy.

3. Parties should confer early in discovery regarding the preservation and production of electronic data and documents when these matters are at issue in the litigation, and seek to agree on the scope of each party's rights and responsibilities.

4. Discovery requests should make as clear as possible what electronic documents and data are being asked for, while responses and objections to discovery should disclose the scope and limits of what is being produced.

5. The obligation to preserve electronic data and documents requires reasonable and good faith efforts to retain information that may be relevant to pending or threatened litigation. However, it is unreasonable to expect parties to take every conceivable step to preserve all potentially relevant data. 
(c) () This work is licensed under a Creative Commons Attribution 4.0 International License

6. Responding parties are best situated to evaluate the procedures, methodologies and technologies appropriate for preserving and producing their own electronic data and documents.

7. The requesting party has the burden on a motion to compel to show that the responding party's steps to preserve and produce relevant electronic data and documents were inadequate.

8. The primary source of electronic data and documents for production should be active data and information purposely stored in a manner that anticipates future business use and permits efficient searching and retrieval. Resort to disaster recovery backup tapes and other sources of data and documents requires the requesting party to demonstrate need and relevance that outweigh the cost, burden and disruption of retrieving and processing the data from such sources.

9. Absent a showing of special need and relevance, a responding party should not be required to preserve, review or produce deleted, shadowed, fragmented or residual data or documents.

10. A responding party should follow reasonable procedures to protect privileges and objections to production of electronic data and documents.

11. A responding party may satisfy its good-faith obligation to preserve and produce potentially responsive electronic data and documents by using electronic tools and processes, such as data sampling, searching or the use of selection criteria, to identify data most likely to contain responsive information.

12. Unless it is material to resolving the dispute, there is no obligation to preserve and produce metadata absent agreement of the parties or order of the court.

13. Absent a specific objection, agreement of the parties or order of the court, the reasonable costs of retrieving and reviewing electronic information for production should be borne by the responding party, unless the information sought is not reasonably available to the responding party in the ordinary course of business. If the data or formatting of the information sought is not reasonably available to the responding party in the ordinary course of business, then, absent special circumstances, the costs of retrieving and reviewing such electronic information should be shifted to the requesting party.

14. Sanctions, including spoliation findings, should only be considered by the court if, upon a showing of a clear duty to preserve, the court finds that there was an intentional or reckless failure to preserve and produce relevant electronic data and that there is a reasonable probability that the loss of the evidence has materially prejudiced the adverse party (Sedona Working Group on Electronic Document Retention and Production, 2007).

In 2009, in a case often referred to as Zubulake 2, Judge Scheindlin granted sanctions against 13 plaintiffs for their failure to properly preserve, collect, and produce 
(c) () This work is licensed under a Creative Commons Attribution 4.0 International License

electronic documents during discovery. She further found that litigants were still conducting electronic discovery in an "ignorant and indifferent fashion." (Pension Comm. of the Univ. of Montreal Pension Plan v. Bank of Am. Sec., LLC,, 2009). The court further found "the failure to issue a written litigation hold constitutes gross negligence because that failure is likely to result in the destruction of relevant information." (Pension Comm. of the Univ. of Montreal Pension Plan v. Bank of Am. Sec., LLC, , 2009)

In addition to citing the plaintiffs' failure to properly preserve, collect, and produce electronic documents, the court also found that six of the 13 plaintiffs were grossly negligent and ordered a jury instruction that applies a burden-shifting test. The jury instruction allowed the jury to: (i) hear and consider evidence pertaining to these plaintiffs' evidence spoliation; and (ii) consider drawing an inference that the lost evidence would have been helpful to the defendants. (Pension Comm. of the Univ. of Montreal Pension Plan v. Bank of Am. Sec., LLC, , 2009).

In the analysis to determine whether the defendants were merely negligent or grossly negligent, the court observed that these litigants had "years of judicial decisions," to guide them in satisfying their duty to preserve electronic evidence. (Pension Comm. of the Univ. of Montreal Pension Plan v. Bank of Am. Sec., LLC, 2009) Therefore, the court further found that any failure to take all appropriate measures to preserve and collect records is "surely negligent." (Pension Comm. of the Univ. of Montreal Pension Plan v. Bank of Am. Sec., LLC, , 2009) Finally, the court found that the parties who failed to follow the steps outlined by Zubulake are mostly likely guilty of gross negligence. (Pension Comm. of the Univ. of
Montreal Pension Plan v. Bank of Am. Sec., LLC,, 2009) The failure to follow the Zubulake outline of preservation standards should warrant imposition of sanctions. (Pension Comm. of the Univ. of Montreal Pension Plan v. Bank of Am. Sec., LLC, 2009) Just as it appeared that the courts were going to hold parties to a very high standard another New York case caused a fury because it rejected the standards put in place by Zubulake and Montreal Pension cases. About the time parties reviewing the current case laws and the Sedona Principles seemed clear that best practices would include a litigation hold, the 2012 Chin case was decided.

\section{RECENT DECISIONS}

The Chin case was decided in the Second Circuit, the same circuit where the Pension case was decided. The Chin decision asserted that the results in the Pension case and others were not reasonable and the case should be decided on the merits and not strictly on discovery failures. The court further decided that the failure to issue a written litigation hold that resulted in the destruction of relevant and unique documents did not constitute gross negligence and did not warrant sanctions (Chin v. Port Authority of New York and New Jersey, 2012).

In the Chin case, 11 Asian-American police officers claimed that they were victims of racial discrimination and brought suit against the Port Authority of New York and New Jersey. The Port Authority had received a litigation notice but still destroyed 32 promotion folders prior to litigation. The defendants did not dispute they had notice to preserve these documents and that the documents contained unique and relevant 
(c) () This work is licensed under a Creative Commons Attribution 4.0 International License

information and that they had failed to issue a written litigation hold. As a result of these facts, the plaintiffs asked the court for an adverse inference against the defendant, Port Authority. The district court denied the motion for adverse inference stating that although the defendant was negligent in failing to preserve the ESI, there was insufficient evidence to show the defendant intentionally destroyed the information. The court further found that the plaintiffs could provide other evidence to prove their claims of discrimination (Chin v. Port Authority of New York and New Jersey, 2012).

On appeal one of the losing plaintiffs asserted that the district court's failure to issue an adverse inference or other sanction was reversible error. Further, the plaintiff argued that the defendant's failure to preserve the data constituted gross negligence per se, and citing Judge Scheindlin in the Pension case. (Opinion and Order, Pension Committee of the Univ. of Montreal Pension Plan, et al., v. Banc of America Securities, LLC, et al., 2010) The Second Circuit held that the district court was correct in its ruling and that a party's failure to issue a litigation hold is not gross negligence per se, nor should it necessarily lead to sanctions (Chin v. Port Authority of New York and New Jersey, 2012). The Second Circuit Court of Appeals agreed with the trial court finding that the failure to preserve this evidence was just "one factor in the determination of whether discovery sanctions should issue." (Chin v. Port Authority of New York and New Jersey, 2012).

The court agreed that a case-by-case approach in determining whether sanctions are appropriate is the correct approach rather than the rules outlined in Judge Scheindlin's Pension case decision (Chin v. Port Authority of New York and New Jersey,
2012). Furthermore, the Second Circuit found that even if a party acted with gross negligence in destroying relevant documents, a trial court has the discretion to impose (or not impose) sanctions based on the totality of the circumstances (Chin v. Port Authority of New York and New Jersey, 2012).

Shortly after the Chin case, Judge Scheindlin made the following finding in the Sekisui case:

"A decade ago, I issued a series of opinions regarding the scope of a litigant's duty to preserve electronic documents and the consequences of a failure to preserve such documents falling within the scope of that duty... Such obligation should, at this point, be quite clear - especially to the party planning to sue." (Sekisui America Corp. v. Hart , 2013)

In this case a group of employees left their company and then the company sued the former employees, discovery ensued, and emails were missing. During discovery, the defendants, Hart and his wife contended that Sekisui should be sanctioned for destroying evidence and sought an adverse inference instruction, arguing that Sekisui acted with "'willful, wanton, and reckless disregard for its discovery obligations."' (Sekisui America Corp. v. Hart , 2013) Sekisui argued that any prejudice to the Harts was minimal and that deleting the e-mails was a mistake, and its lawyers disclosed the deletion to the Harts' counsel and the HR manager authorized the deletion of the e-mail folders. Regardless the deletion, the attorney was able to retrieve 36,000 e-mails. In addition, Sekisui argued that the e-mails were irrelevant to the claims in the lawsuit.

The court evaluated three factors to determine whether an adverse inference instruction was appropriate: "(a) the party 
(c) () This work is licensed under a Creative Commons Attribution 4.0 International License

having control over the evidence had an obligation to preserve it; (b) the records were destroyed with a 'culpable state of mind'; and (c) the destroyed evidence was 'relevant' to the moving party's claim or defense, 'such that a reasonable trier of fact could find that it would support that claim or defense." (Sekisui America Corp. v. Hart , 2013) The court found Sekisui's failure to impose litigation hold when it filed its notice of claim was negligent and led directly to the destruction of the e-mails and "may well rise to the level of gross negligence." (Sekisui America Corp. v. Hart , 2013) Judge Scheindlin ruled that an adverse inference jury instruction might be entered against a party that destroys evidence knowingly or even negligently and even in the absence of prejudice to the adverse party. (Sekisui America Corp. v. Hart , 2013) Several other cases did not impose sanctions because the failure to maintain a litigation hold was not gross negligence. Herrmann v. Rain Link, Inc., No. 11-1123-RDR, 2013 WL 4028759 (D. Kan. Aug. 7, 2013).

In other 2013 cases different courts hearing cases with similar facts have come to different conclusions. The controlling question that affects the court's decision is whether the court finds failure to institute a litigation hold is gross negligence per se, or is it mere negligence. Those cases finding the omission was mere negligence tend not to sanction the parties. In cases in which the court finds that not instituting a litigation hold is gross negligence, sanctions are generally issued. At the same time, based on the Steinberg Group survey, the trend is for companies to defend their preservation practices. "From 2013 to 2014, the number of participants that have defended practices moved from $21.8 \%$ to $31 \%$ (Steinberg, page $22)$. In this same survey, $52 \%$ of the responding companies issue a litigation hold in more than $75 \%$ of their matters. In addition, these companies were asked to rate their risk with their method of implementing litigation holds. More than a majority of those companies using automated processes saw themselves at low risk, while those implementing manual processes saw themselves at medium risk. Those using verbal processes saw themselves as either high risk or medium risk (Steinberg Group LLC).

In Pradaxa the court found sanctions were warranted for defendants' failure to follow the management orders and for bad faith. (Pradaxa (Dabigatran Etexilate) In Herrmann v. Rain Link, Inc. the court refused sanctions finding that the spoliation is mere negligence. (Herrmann v. Rain Link, Inc.) In Cottle-Banks v. Cox the court found the defendant had a culpable state of mind when it failed to preserve data. The court subsequently ordered the defendant to pay more than $\$ 250,000,000$.

In 2014 Brown v. Tellermate the court confirmed the duty to preserve information in the cloud. In this case the plaintiffs, Robert and Christine Brown (Browns), sought information concerning their sales records from their former employer in order to substantiate their age discrimination suit. Most of their sales records were stored in the cloud by Salesforce, a cloud provider. Plaintiffs claimed they had either met or exceeded their sales quotas compared to younger employees. The employer's lawyer did issue a general directive that relevant documents must be preserved neither the employer or its lawyer did any meaningful follow-up. The court found specifically that the attorney for Tellermate failed to do the following: 
(c) () This work is licensed under a Creative Commons Attribution 4.0 International License

- To uncover even the most basic information about an electronically stored database (Salesforce)

- Took no steps to preserve the integrity of the information in the database.

- To learn about a prior age discrimination charge

- As result made statements that were misleading and false to the court and the Browns' attorney

The employer failed to maintain its cloud account. The court sanctioned the employer by not allowing them to use any evidence to show they terminated the employees for any performance related reasons. In addition, the employer was ordered to pay the plaintiff's attorney fees and costs for a year's worth of discovery motions. One of the lessons that should be learned from this case is that companies and attorneys must understand how the cloud works and that litigation holds extend to the cloud. In another 2014 case (Vicente v City of Prescott 2014 WL 3894131 (D. Ariz. August 8, 2014) the plaintiffs sought sanctions against the defendants because they failed to preserve electronic data. The defense was that the information never existed. The courts found that the defendants' arguments to be altogether unpersuasive and that the defendants' preservation effort was plainly deficient. In yet another 2014 case (Riley v Marriot Int. 2014 WL 4794657 (W.D. N.Y. Sept 25, 2014) the court granted sanctions for defendants' failure to preserve evidence as gross negligence. In this case the plaintiff fell in the defendant's hotel garage. Although there was testimony that this area was consistently monitored and video surveillance was maintained for 30 days, the defendants failed to preserve the tape. The court found that "the failure to provide the Court with any sworn facts from persons with knowledge of the destruction of the challenged evidence demonstrates such a lack of diligence that it suggest bad faith destruction." The court granted an adverse inference instruction.

In the case In Re Actos, the court sanctioned the defendants for spoliation after 46 custodial files and the ESI in those files were lost, destroyed or rendered inaccessible. In Polo-Calderon v. Corporation Puetorriquena de Salud, the court sanctioned one of the plaintiffs for failing to preserve text messages sent and received by him. In general, these cases provide evidence that companies must adopt and enforce a litigation hold process and procedure, preferably in writing. This practice will show the court and the opposing party that the company is seriously making every effort to comply with litigation hold requirements, and that any mistakes are mere negligence and not gross negligence. (49 Orange County Lawyer 18 "Litigation Holds: Best Practices for Protecting your company's email data from inadvertent loss and spoliation. R. Jeffrey Graham).

The company's law firm can also be sanctioned and have ethical issues if an attorney knows a litigation hold should have been in place and does not properly implement and monitor the process. Crystal, Nathan Ethical Responsibility and Legal Liability of Lawyers for failing to monitor litigation holds.

To determine the changes in company practices from 2013 to 2014, the Steinberg Group, a marketing research company, conducted a survey of 536 companies on their litigation hold practices. (Litigation Hold and Data Preservation Benchmark Survey 2014 Report) commentary by Brad Harris. Based on the survey, 53\% (Steinberg Group p7) of the surveyed organizations issued litigation holds in pending litigation matters, but only 
(c) () This work is licensed under a Creative Commons Attribution 4.0 International License

$44 \%$ of these companies used automated legal holds by software (Steinberg Group p 18). The most important finding in this survey was that less than half of the legal holds go any further than a hold (p24) and only four percent go to litigation. (p24) Further, fewer than three percent actually go to trial. (p25)

\section{NEW DISCOVERY RULES}

On May 29, 2014 the Committee on Rules of Practices and Procedure met to amend the rules of Civil Procedure including Rule 37(e) that is presently the safe harbor rule. If adopted, this rule will make it more difficult for courts to order sanctions. The new rules if passed will read as follows:

Rule 37(e) Failure to Preserve Electronically Stored Information.

If electronically stored information that should have been preserved in the anticipation or conduct of litigation is lost because a party failed to take reasonable steps to preserve it, and it cannot be restored or replaced through additional discovery, the court:

(1) upon finding prejudice to another party from loss of the information, may order measures no greater than necessary to cure the prejudice; or

(2) only upon finding that the party acted with the intent to deprive another party of the information's use in the litigation, may:

(A) presume that the lost information was unfavorable to the party;

(B) instruct the jury that it may or must presume the information was unfavorable to the party; or
(C) dismiss the action or enter a default judgment.

If this rule passes it will foreclose the use of sanctions in most cases, but before companies decide to forego their litigation practices, they will still need to be in compliance with agency requirements such as Sarbanes-Oxley, HIPPA and others that will still require strict maintenance of ESI. See, e.g., 18 U.S.C. § 1519 (Sarbanes-Oxley Act § 802).

\section{CONCLUSION AND FUTURE DIRECTIONS}

In conclusion, it is apparent that after 10 years of consistent decisions and best practices regarding the requirement of a litigation hold, the state of the law regarding litigation holds in now in flux with no apparent resolution in sight. Even with the cases that seemingly dilute the requirement of a litigation hold and the possibility of new rules, parties and potential parties to litigation should still follow the Sedona Conference Principles best practices and to prevent the possible imposition of sanctions. If companies have a good litigation plan that includes frequent education of employees, demonstrates a reasonable effort to follow the plan, and certainly takes prompt action when the plan fails, litigation sanctions can be avoided or minimized. Companies that follow best practices and audit their procedures regularly are the companies for which the safer harbor provisions of rules of Federal Rules of Civil procedure were designed (Federal Rules of Civil Procedure, 2006).

In conclusion, it is apparent that after 10 years of consistent decisions and best practices regarding the requirement of a litigation hold, the state of the law regarding 
(c) (i) This work is licensed under a Creative Commons Attribution 4.0 International License.

litigation holds in now in flux with no apparent resolution in sight. Even with the cases that seemingly dilute the requirement of a litigation hold and the possibility of new rules, parties and potential parties to litigation should still follow the Sedona Conference Principles best practices and to prevent the possible imposition of sanctions. If companies have a good litigation plan that includes frequent education of employees, demonstrates a reasonable effort to follow the plan, and certainly takes prompt action when the plan fails, litigation sanctions can be avoided or minimized. Companies that follow best practices and audit their procedures regularly are the companies for which the safer harbor provisions of rules of Federal Rules of Civil procedure were designed (Federal Rules of Civil Procedure, 2006). 
(c) () This work is licensed under a Creative Commons Attribution 4.0 International License REFERENCES

Chin v. Port Authority of New York and New Jersey, No. 10-1904 -cv(L), 2012 U.S. App. LEXIS 14088 (2d Cir. July 10, 2012).

Crystal, Nathan Ethical Responsibility and Legal Liability of Lawyers for failing to monitor litigation holds.

Federal Rules of Civil Procedure, Rule 37 (December 2006).

Governance, e. G. (2012). How Companies Manage Litigation Holds . Oregon: eDJ Group.

Herrmann v. Rain Link, Inc., No. 11-1123RDR, 2013 WL 4028759 (D. Kan. Aug. $7,2013)$

Opinion and Order, Pension Committee of the Univ. of Montreal Pension Plan, et al., v. Banc of America Securities, LLC, et al., No. 05-civ-9016 (SAS (2010).

Pension Comm. ofthe Univ. of Montreal Pension Plan v. Bane ofAm. Sec., LLC, 685 F. Supp. 2d 456,466 (S.D.N.Y Jan 5, 2009).

Sedona Working Group on Electronic Document Retention and Production. (2007). Sedona Conferences Commentary on Legal Holds The Trigger and Process. Sedona Working Papers (p. 20). Sedona: Sedona Group.

Sekisui America Corp. v. Hart, No. 12 Civ. 3479 (SAS) (FM),2013 U.S. Dist. LEXIS 84544 (S.D.N.Y June 10, 2013).

Zubulake v. UBS Warburg, 229 F.R.D. 422 (S.D.N.Y 2004).

Zubulake v. UBS Warburg, , 216 F.R.D. 280 (S.D.N.Y 2003). 